\title{
Powdery mildew of Allium species caused by Oidiopsis taurica in Brazil
}

\author{
Ailton Reis ${ }^{1}$; Leonardo S. Boiteux ${ }^{1,3}$; Milton L. Paz-Lima ${ }^{2}$; Patrícia P. Silva ${ }^{1,3}$; Carlos A. Lopes ${ }^{1,3}$ \\ ${ }^{1}$ Embrapa Hortaliças, C Postal 218, 70359-970 Brasília-DF; ${ }^{2}$ Universidade de Brasília (UnB), Depto. Fitopatologia, C. Postal 4457, \\ 70910-900 Brasília-DF; ${ }^{3}$ CNPq Fellowship. E-mail: boiteux@cnph.embrapa.br
}

\begin{abstract}
Oidiopsis taurica Salmon (Syn. Oidiopsis sicula Scalia) was identified as the causal agent of a powdery mildew disease occurring on distinct Allium species in Brazil. This disease was initially observed in plastic house and field-grown garlic (Allium sativum) and leek (A. porrum) accessions in Brasília (Federal District) and in field-grown and greenhouse onion (A. cepa) cultivars in Belém do São Francisco (Pernambuco State) and Brasília, respectively. Typical symptoms consisted of chlorotic areas on the leaf surface corresponding to a fungal colony. These lesions turned to a brownish color with the progress of the disease. Fungi morphology was similar to that described for $O$. taurica. Endophytic mycelium emerging through estomata, light pale conidia were dimorphic (lanceolate primary conidia and somewhat cylindrical secondary conidia), fibrosin bodies were absent, conidia formed predominantly single (not in chains), and appressoria were non-lobed. Its sexual stage, Leveillula taurica (Lev.) Arnaud, was not observed. Inoculations were performed with the $O$. taurica isolates from distinct Allium hosts. These isolates were also pathogenic to sweet pepper and tomato, indicating an apparent absence of host specialization. One bunching onion (A. fistulosum) accessions was not infected by $O$. taurica suggesting that this species might carry useful resistance alleles to this pathogen. This is the first formal report of a powdery mildew disease on species of the genus Allium in Brazil. This disease might become important on these vegetable crops especially in hot and dry areas such as those in the Central and Northeast regions of Brazil.
\end{abstract}

Keywords: Leveillula taurica, Allium cepa, A. porrum, A. sativum, etiology.

\section{RESUMO}

Oídio em espécies do gênero Allium, causado por Oidiopsis taurica, no Brasil

O fungo Oidiopsis taurica Salmon (= Oidiopsis sicula Scalia) foi identificado como sendo o agente causal de uma nova doença do tipo oídio em alho (Allium sativum), alho porró (A. porrum) e cebola (A. серa) no Brasil. Esta doença foi observada tanto em condições de casa de vegetação quanto a campo em Brasília e Pernambuco. O sintoma mais típico é o aparecimento de uma área clorótica na superfície da lâmina foliar que corresponde a uma colônia fúngica. Com o progresso da doença, estas lesões tornaram-se marons. As características morfológicas do fungo, corresponderam àquelas descritas para $O$. taurica, incluindo micélio endofítico emergindo através das aberturas estomáticas, conídio solitários de coloração hialino-amarelada, ausência de corpos de fibrosina, apressório não-lobado e a presença de dois tipos diferenciados de conídios sendo um primário (de formato predominantemente lanceolado) e um secundário (de formato tendendo ao cilíndrico). O estádio sexual Leveillula taurica (Lev.) Arnaud, não foi observado em nenhuma das plantas hospedeiras. Estudos de inoculação cruzada, utilizando isolados obtidos destas diferentes espécies de Allium, não forneceram nenhum indício de especialização por hospedeira. Os isolados originários das espécies de Allium foram também patogênicos a plantas de pimentão e tomate. $\mathrm{O}$ acesso de cebolinha (A. fistulosoum) avaliado não foi infectados por nenhum dos isolados, indicando a utilidade desta espécie como uma potencial fonte de resistência a este patógeno. Este é o primeiro registro deste patógeno afetando espécies do gênero Allium no Brasil. Este oídio pode se tornar importante para o cultivo destas hortaliças em condições de clima quente e seco, tais como observados em alguns períodos do ano no Brasil Central e no Nordeste.

Palavras-chave: Leveillula taurica, Allium cepa, A. porrum, A. sativum, etiologia.

(Recebido para publicação em 26 de abril de 2004 e aceito em 03 de setembro de 2004)

$\mathrm{T}$ The Alliaceae family comprises one of the leading groups of plants in terms of economic importance, including major vegetable crops such as garlic (Allium sativum L.), leek (A. porrum L. syn. A. ampeloprasum), onion (A. cepa L.), and bunching onion (A. fistulosum L.) (Brewster, 1994). In Brazil, these vegetables are primarily cultivated under open field conditions. However, seedlings for transplantation, plants employed in controlled crosses during breeding programs, and tissue culture-derived virus-free garlic plantlets are often cultivated under either greenhouse or plastic house conditions.
A number of foliar diseases caused by fungi are reported on Allium species including Alternaria leaf blight (Alternaria porri (Ellis) Cif.), Stemphylium blight (Stemphylium spp.) and downy mildew (Peronospora destructor (Berk.) Casp.) (Maffia et al., 2002; Zambolim et al., 2000). However, an apparently undescribed powdery mildew disease was observed affecting a range of Allium species in distinct Brazilian growing regions. This disease was first noticed on garlic and leek accessions in Brasília (Federal District) and in field-grown onion cultivars in
Belém do São Francisco (Pernambuco State) during successive growing seasons (from 2000 to 2003). In this work, the occurrence of a powdery mildew disease on Allium species in Brazil was described as being caused by the fungus Oidiopsis taurica Salmon (syn. O. sicula Scalia).

\section{MATERIAL AND METHODS}

Open field-grown plants of leek showing atypical powdery mildew-like symptoms were collected in Brasília (Federal District). Similar symptoms 
were observed in leaf samples of fieldgrown onion plants cultivated under overhead drip irrigation in Belém do São Francisco, Pernambuco State. Tissueculture derived garlic and onion plants cultivated under greenhouse conditions in Brasília also presented these atypical symptoms. Sampled plants were taken to the Plant Pathology Laboratory of Embrapa Hortaliças. The affected leaf tissue was visualized under stereomicroscope, symptomatic leaf sections were removed and the fungal structures were visualized in microscope slides prepared by mounting thin host tissue slices in lactophenol. Measurements of length and width were taken using 30 primary and 30 secondary conidia (chosen randomly) that were collected from each host described in this investigation. Other morphological aspects of the fungal structures associated with the imperfect stages of powdery mildew fungi (Boesewinkel, 1980; Palti 1959; Palti, 1988) were observed including color of conidia, presence of fibrosin bodies, vacuoles and type of germination tube. Pathogenicity tests were performed inoculating separately a group of test plants with five isolates obtained from sweet pepper, tomato, onion, garlic and leek. The following plants were used in the pathogenicity tests: $A$. cepa "Alfa Tropical", A. porrum, A. fistulosum, A. sativum "Amarante", tomato (Lycopersicon esculentum Mill.) cultivars Santa Clara and Ponderosa as well as sweet pepper (Capsicum annuиm L.) cv. Margarita. Tomato and sweet pepper were included in this test because they have been reported as hosts of similar type of powdery mildew disease in Brazil. These test plants were cultivated in $5 \mathrm{~L}$ plastic pots (three pots with two plants per pot) with sterile soil. Thus, a total of six plants of each test species were inoculated with each isolate. Plants were inoculated by leaf to leaf contact at 45 days after planting. The development of powdery mildew symptoms was assessed 15 days after inoculation.

\section{RESULTS AND DISCUSSION}

Plants of leek collected in Brasília displayed disease symptoms characterized by yellow spots corresponding to the establishment of a fungal colony. As disease progressed the yellow spots turmed a light brown color.

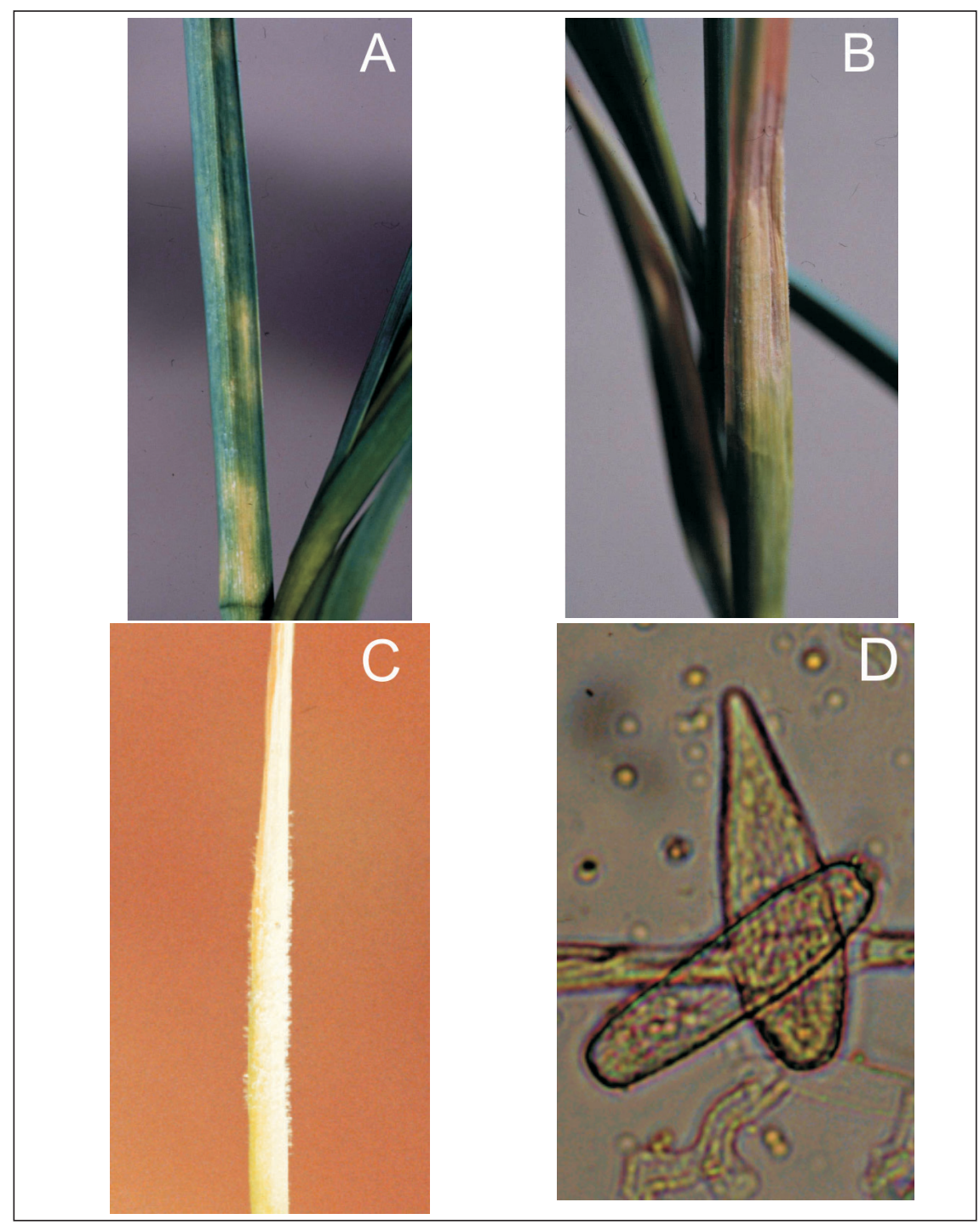

Figure 1. Initial (A) and advanced (B) symptoms of powdery mildew on garlic, symptoms in onion (C) and primary (a) and secundary (b) conidia of the causal agent, Oidiopsis taurica (D), collected from garlic. Brasília, Embrapa Hortaliças, 2004.

Similar symptoms were also observed in leaf samples of field-grown onion from Belém do São Francisco. Tissue-culture derived garlic plants and onion plants cultivated under greenhouse conditions in Brasília displayed identical symptoms (Figures 1A to 1C).

Observations on the light microscope revealed that most mycelia are endophytic with the presence of conidiophores emerging through leaf stomata. Some conidiophores were divided into two to three branches. Ellipsoidal, light pale conidiospores (conidia) were borne predominantly single and terminally on the conidiogenic cell. The main light microscopy and host range diagnostic characters of $O$. taurica were in complete agreement with the synoptic table of Cook et al. (1997) including: large primary conidia with lanceolate shape and secondary conidia with a cylindrical shape (Figure 1-D-a and b), absence of fibrosin bodies, presence of endophytic mycelicum and not-lobed appressoria. The mean measurements taken from primary conidia from infected leek tissue were on average $58,2 \mu \mathrm{m}$ (length) $\times 15,4 \mu \mathrm{m}$ (width) and $53,2 \mu \mathrm{m} \times 15,4 \mu \mathrm{m}$ for the secondary conidia. Conidia length/width ratio were within a similar range for garlic and onion isolates, and also for sweet pepper isolate, used as a standard (Table 1). These intervals were somewhat smaller than that observed in some solanaceous hosts but they are still in the range reported in the literature for $O$. taurica (Boisewinkel, 1980; Braun, 1987; Cook 
Table 1. Length and diameter of primary and secondary conidia of Oidiopsis taurica from Allium hosts and Capsicum annuum. Brasília, Embrapa Hortaliças, 2004.

\begin{tabular}{|c|c|c|c|c|}
\hline \multirow{2}{*}{ Host } & \multicolumn{2}{|c|}{ Primary conidia* } & \multicolumn{2}{|c|}{ Secondary conidia* } \\
\hline & Range & Average & Range & Average \\
\hline Allium porrum & $49,6-73,6 \times 14,8-19,5$ & $58,2 \times 15,4$ & $56,8-69,3 \times 13,6-18,5$ & $53,2 \times 15,4$ \\
\hline Allium cepa & $54,4-71,2 \times 12,6-18,9$ & $59,9 \times 15,6$ & $53,5-70,1 \times 13,3-19,1$ & $58,5 \times 15,1$ \\
\hline Allium sativum & $50,8-71,2 \times 14,1-18,8$ & $57,9 \times 15,3$ & $55,1-68,1 \times 14,8-17,7$ & $56,3 \times 15,2$ \\
\hline Capsicun annuun (standard) & $60,2-75,4 \times 13,6-19,0$ & $63,0 \times 15,3$ & $58,4-71,2 \times 13,3-19,6$ & $62,4 \times 14,7$ \\
\hline
\end{tabular}

"Length and diameter, measured in $\mu \mathrm{m}$

et al., 1997; Liberato et al., 1998; 2000). Koch's postulates were fulfilled for all Allium species. Host range studies indicated that $O$. taurica isolates from Allium species are also virulent on solaneceous crops such as sweet pepper and tomato. Therefore, there was no clear indication of host specialization of these isolates. Interestingly, the bunching onion (A. fistulosum) accession was not infected by $O$. taurica.

Powdery mildew caused by $O$. taurica affecting onion and/or garlic has been reported in Sudan (Schwartz \& Mohan, 1996), United States (Laemmlen \& Endo, 1985) and Israel (Palti, 1959) but this is apparently the first report of this disease in Brazil (Café Filho et al., 2001; Maffia et al., 2002; Mendes et al., 1998). To our knowledge there is no report describing leek as a host of $O$. taurica. The sexual stage (Leveillula taurica) was not observed in the leaf samples of any host plant throughout this investigation. Fungal isolates from Allium species were capable of infecting sweet pepper and tomato plants. Likewise, isolates from tomato and sweet pepper were able to infect Allium species. This is in agreement with the notion that $O$. taurica is an atypical powdery mildew since it has a wide host range usually not observed for obligate parasites members of the Erysiphaceae family (Boesewinkel, 1980; Café Filho et al., 2001; Liberato et al., 1998; 2000; Paz Lima et al., 2002; Reis, et al., 2004; Silva et al., 2003).

Severe outbreaks of powdery mildew in sweet pepper and tomato caused by $O$. taurica were initially reported uder plastic house conditions in Brazil (Boiteux et al., 1994; Liberato et al., 1998; 2000; Santos \& Boiteux, 1994). However, this powdery mildew disease is now economically important for tomato and sweet pepper under both plastic house and open-field conditions. Therefore, the wide host range of $O$. taurica (including new Allium species) could have important epidemiological implications when establishing disease control strategies for both Alliaceae and Solanaceae crops. This powdery mildew disease might also become important on some of these Allium crops especially in hot and dry areas where drip irrigation is employed as well as in special situations where cultivation under either plastic house or greenhouse is necessary, as for seed production and for clonal propagation.

An interesting result from the breeding standpoint is the non-host response of the A. fistulosum accession suggesting that this species might be a useful reservoir of powdery mildew resistance genes. Screening of onion germplasm for resistance to $O$. taurica is underway. The development of resistant cultivars would be one of the most practical and economical strategies to control this disease.

\section{CITED LITERATURE}

BOESEWINKEL H.J. The morphology of the imperfect states of powdery mildews (Erysiphaceae). The Botanical Review, v.46, p.167-224, 1980.

BOITEUX, L.S.; SANTOS, J.R.M.; LOPES, C.A First record of powdery mildew of sweet-pepper (Capsicum annuиm) incited by Leveillula taurica in Brazil. Fitopatologia Brasileira, Brasília, v.19, supl., p.304, 1994. (Abstract).

BREWSTER J.L. Onions and Other Vegetable Allium. CAB International Wallingford, United Kingdom. 1994. 236 p.

BRAUN, U. A monograph of the Erysiphales (powdery mildews). Nova Hedwigia. v.89, p.1700, 1987.

CAFÉ FILHO, A.C.; COELHO, M.V.S.; SOUZA, V.L. Oídios de Hortaliças. In: Stadnik, M.J.; Rivera M.C. Oídios. Jaguariúna: Embrapa Meio Ambiente, 2001. cap.11, p.285-302.
COOK R.T.A.; INMAN A.J.; BILLINGS C. Identification and classification of powdery mildew anamorphs using light and scanning electron microscopy and host range data. Mycological Research, v.101, n.8, p.975-1002, 1997.

LAEMMLEN, F.F.; ENDO, R.M. Powdery mildew (Oidiopsis taurica) on onion in California. Plant Disease, v.69, p.451, 1985.

LIBERATO, J.R. LOURO, R.P.; SUZUKI, M.S.; BARRETO, R.W. Ocorrência de oídio do tomateiro causado por Oidiopsis no Estado do Rio de Janeiro. Fitopatologia Brasileira, Brasília, v.23,n.1,p.81, 1998. LIBERATO, J.R. CUNHA, M.; SUZUKI, M.S.; SILVEIRA, S.F. Ocorrência do oídio do pimentão causado por Oidiopsis sp. no Estado do Espírito Santo. Fitopatologia Brasileira, Fortaleza, v.25, n.1, p. 110, 2000

MAFFIA, L.A.; MIZUBUTI, E.S.G.; PEDROSA, R.A. Doenças da cebola. Informe Agropecuário, Belo Horizonte, v.23, n.218, p.75-87, 2002. MENDES, M.A.S.; SILVA, V.L.; DIANESE, J.C.; FERREIRA, M.A.S.V.; SANTOS, C.E.N.; GOMES NETO, E.; URBEN, A.F.; CASTRO, C. Fungos em Plantas no Brasil. Brasília, EmbrapaSPI, Embrapa Cenargen, 1998. 555 p.

PALTI, J. Oidiopsis diseases of vegetable and legume crops in Israel. Plant Disease Reporter, v.43, p.221-226, 1959.

PALTI, J. The Leveillula mildews. The Botanic Review, v.54, n.4, p.423-535, 1988.

PAZ LIMA, M.L.; BOITEUX, L.S.; REIS, A.; COSTA, S.B.; LOPES, C.A. Alho porró: Hospedeiro de Oidiopsis taurica no Brasil. Fitopatologia Brasileira, Fortaleza, v.27, supl., p.126, 2002. (Resumo).

REIS, A.; LOPES, C.A.; PAZ-LIMA, M.L.; BOITEUX, L.S. Eryngium foetidum, Petroselinum crispum and Coriandrum sativum: New Apiaceae hosts of Oidiopsis taurica in Brazil. Fitopatologia Brasileira, Fortaleza, v.29, n.3, p.339, 2004.

SANTOS, J.R.M.; BOITEUX L.S. Ocorrência de oídio (Leveillula taurica e Erysiphe cichoracearum) em tomateiro no Distrito Federal. Fitopatologia Brasileira. Brasília, v.19, supl., p.313, 1994. (Abstract).

SILVA, P.P.; LOPES, C.A.; REIS, A.; PAZ LIMA, M.L.; BOITEUX, L.S. Eryngium foetidum, Petroselinum crispum, Coriandrum sativum e Solanum tuberosum: Novas hospedeiras de Oidiopsis taurica no Brasil. Fitopatologia Brasileira, Fortaleza, v.28, supl., p.214, 2003. (Abstract).

SCHWARTZ, H.F.; MOHAN, S.K. Compedium of Onion and Garlic Diseases. APS Press, St. Paul, 54 p. 1996.

YARWOOD, C.E. History and Taxonomy. In SPENCER, D.M. The Powdery Mildews. London: Academic Press, 1978. cap.1, p.1-28.

ZAMBOLIM, L.; VALE, F.X.R.; COSTA, H. Controle de Doenças de Plantas: Hortaliças. Viçosa: Universidade Federal de Viçosa, v.1. 879 p. 2000. 